\title{
LCA in the Field of Safety at Work: A New Engineering Study Subject
}

\author{
Boris Agarski, Dejan Ubavin, Djordje Vukelic, Milana Ilic Micunovic, \\ and Igor Budak
}

\begin{abstract}
Life cycle assessment (LCA) is a standardised and comprehensive approach for evaluation of environmental impacts within the material and energy flows associated with various human activities and through the life cycle stages. Besides environmental impact evaluation, with LCA, costs, social impacts, impacts on workers, organisations and others can also be assessed. This paper focuses on development of educational framework for evaluation of occupational safety based on LCA. The goal is to develop a new study subject "LCA in the field of safety at work" for the occupational safety engineering master study programme at the Faculty of Technical Sciences in Novi Sad. New study subject is based on LCA approaches that evaluate the occupational safety and impact on workers. Based on the previous research of LCA in the field of occupational safety, the goal, outcome, content and realisation are defined for the new study subject.
\end{abstract}

\section{Introduction}

Life cycle assessment (LCA) has been in education process at the University of Novi Sad for more than 20 years, since the foundation of the Department of Environmental Engineering at the Faculty of Technical Sciences. The starting point was a teaching topic within the environmental engineering study programme, the subject mechanical engineering in environmental protection. Today, LCA is studied in several courses at bachelor, master and $\mathrm{PhD}$ levels of environmental, occupational safety, mechanical and civil engineering study programmes. The result is a growing number of bachelor, master and $\mathrm{PhD}$ theses in the field of LCA, ecolabelling and eco-design. Considering the importance of occupational safety in engineering and aiming to fulfil the expectations of organisations operating on the labour market, besides the environmental engineering, since 2010 occupational safety engineering study programme has been established at the Faculty of Technical Sciences.

B. Agarski $(\bowtie) \cdot$ D. Ubavin · D. Vukelic · M. I. Micunovic $\cdot$ I. Budak

Faculty of Technical Sciences, University of Novi Sad, Novi Sad, Serbia

e-mail: agarski@uns.ac.rs 
Besides environmental LCA, life cycle costing and social LCA (S-LCA) emerge in order to provide sustainable LCA, where S-LCA is the youngest methodology. Within the S-LCA [1], impact on workers' health and safety during the life cycle is a group of stakeholder impact categories that can provide information on accident rates at workplace (non-fatal and fatal), occurrence of various diseases and injuries, disability-adjusted life years (DALYs), presence of safety measures, etc. Working environment LCA (WE-LCA) [2] aim to compile and evaluate potential working environmental impacts on humans of a product system throughout its life cycle. The impact categories in WE-LCA can be expressed through evaluation of potential accidents and diseases: fatal accidents, total number of accidents, central nervous system function disorder, hearing damages, cancer, musculoskeletal disorders, airway diseases (allergic and non-allergic), skin diseases and psychosocial diseases. Furthermore, damage to human health attributable to the work environment can be assessed as DALYs [3].

Table 1 provides several approaches for WE-LCA. Schmidt et al. [2] developed one of the first WE-LCA approaches. This WE-LCA approach is based on EDIP life cycle impact assessment method and contains a small life cycle inventory (LCI) database with more than 80 activities. Pettersen and Hertwich [4] focused on evaluation of safety issues related to offshore crane lifts working environment. Kim and Hur [5] developed two working environment indicators in context of LCA: occupational health and occupational safety. One of the first S-LCA case studies that followed the UNEP/SETAC S-LCA guidelines [1] was presented transparently and in detail was realised by Ciroth and Franze [6]. Group of authors [3, 7] provided two papers published in 2013 and 2014 and used national occupational safety and health industry statistics for United States of America to express the impact on working environment through the WE-DALY units. For WE-DALY indicator, they [3] provided 127 working environment characterisation factors linked with various industry sectors. Kijko et al. [8] also used DALY units to assess health impacts from occupational exposure to chemicals. Khakzad et al. [9] used LCA and quantitative risk assessment methods in parallel to obtain the environmental and safety assessment. Monetary valuation, Canadian dollar (CAD) units were used for both methods in order to have comparable outputs from LCA and quantitative risk assessment.

It can be noted that all approaches in Table 1 have the following common characteristics:

- Compatible with ISO 14040 LCA phases and environmental LCA.

- National statistic records of safety issues through the industrial sectors are used to evaluate safety at work, or to assess the risk of injuries and illness.

- Although developed on national level, all approaches have the potential for universal worldwide use.

Considering that the working environment indicators are relatively new topic in LCA, and that research in the field of S-LCA is an actual topic nowadays, this paper focuses on development of educational framework for LCA in the field of safety at work and working environment in LCA. The goal of this paper is to develop a new study subject on a master study programme of occupational safety engineering at 
Table 1 LCA approaches to evaluate safety at work

\begin{tabular}{|c|c|c|c|}
\hline Approach & $\begin{array}{l}\text { Working environment in life } \\
\text { cycle assessment }\end{array}$ & $\begin{array}{l}\text { Human health } \\
\text { impact indicator } \\
\text { for offshore crane } \\
\text { lifts }\end{array}$ & $\begin{array}{l}\text { Hybrid input-output } \\
\text { analysis }\end{array}$ \\
\hline Acronym & WE-LCA & - & Hybrid IOA \\
\hline Reference & [2] & [4] & {$[5]$} \\
\hline Developing basis & EDIP $^{\mathrm{b}}$ method & $\begin{array}{l}\text { LCA and DALY } \\
\text { units }\end{array}$ & LCA and IOA method \\
\hline Problem-solving & Impacts on workers/universal & $\begin{array}{l}\text { Development of a } \\
\text { human health } \\
\text { impact indicator } \\
\text { for offshore crane } \\
\text { lifts }\end{array}$ & $\begin{array}{l}\text { Assessment of } \\
\text { occupational health and } \\
\text { safety }\end{array}$ \\
\hline Geography & Denmark & United Kingdom & Korea \\
\hline Characterisation & $\begin{array}{l}\text { Based on statistics on } \\
\text { work-related accidents and } \\
\text { reported diseases from the } \\
\text { Danish Labour Inspectorate } \\
\text { and Statistics on the amounts } \\
\text { of produced goods in } \\
\text { Denmark }\end{array}$ & $\begin{array}{l}\text { Based on number } \\
\text { of crane lift } \\
\text { incident injuries } \\
\text { and expressed in } \\
\text { DALY per crane } \\
\text { lift }\end{array}$ & $\begin{array}{l}\text { Linking the LCI data } \\
\text { with } 28 \text { basic industrial } \\
\text { sectors classified by the } \\
\text { Bank of Korea for } \\
\text { occupational health and } \\
\text { Korea Occupational } \\
\text { Safety and Health } \\
\text { Agency for occupational } \\
\text { safety }\end{array}$ \\
\hline $\begin{array}{l}\text { No. of impact } \\
\text { categories }\end{array}$ & $\begin{array}{l}10 \text { - fatal accidents, total } \\
\text { number of accidents, hearing } \\
\text { damages, cancer, } \\
\text { musculoskeletal disorders, } \\
\text { airway diseases (allergic), } \\
\text { airway diseases (non- } \\
\text { allergic), skin diseases, } \\
\text { psychosocial diseases, CNS } \\
\text { function disorder }\end{array}$ & $\begin{array}{l}1 \text { - health burden } \\
\text { per crane lift }\end{array}$ & $\begin{array}{l}2 \text { - occupational health } \\
\text { (number of workers } \\
\text { affected by certain } \\
\text { hazardous items) and } \\
\text { occupational safety } \\
\text { (number of workers at } \\
\text { certain magnitude of } \\
\text { disability) }\end{array}$ \\
\hline Normalisation & $\begin{array}{l}\text { Yes }-2 \text { sets: Danish } \\
\text { population (person } \\
\text { equivalents) and Danish work } \\
\text { force (worker equivalents) }\end{array}$ & $\begin{array}{l}\text { Yes - number of } \\
\text { lifts performed } \\
\text { per hour }\end{array}$ & $\begin{array}{l}\text { Yes - total national lost } \\
\text { work days from the } \\
\text { occupational diseases by } \\
\text { hazardous items during } \\
\text { the given period of time } \\
\text { divided by the total } \\
\text { number of the workers }\end{array}$ \\
\hline $\begin{array}{l}\text { Developed and } \\
\text { provided } \mathrm{LCI}^{\mathrm{a}} \\
\text { database }\end{array}$ & $\begin{array}{l}\text { Yes - more than } 80 \text { activities } \\
\text { based on DB93c industry } \\
\text { sectors }\end{array}$ & No & No \\
\hline
\end{tabular}

${ }^{a} \mathrm{LCI}$, life cycle inventory

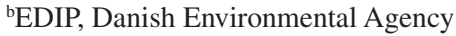

'DB93, Danish nomenclature for industry sectors (identical to the EU NACE-code system)

${ }^{\mathrm{d}} D A L Y$ disability-adjusted life years 
the Faculty of Technical Sciences in Novi Sad in order to produce occupational safety engineers that will be able to assess the impacts on workers' health and safety with LCA approach.

\section{Methodology}

The study programme of the graduate master academic studies in Occupational Safety Engineering presents the continuation of the undergraduate academic studies of Occupational Safety Engineering at the Faculty of Technical Sciences, University of Novi Sad [10]. Engineering and technical disciplines are incorporated into the realisation of the curriculum of the undergraduate and graduate academic studies of Occupational Safety Engineering, thus representing a highly multidisciplinary and interdisciplinary programme. The study programme prerequisites for the enrolment are completed undergraduate studies with at least 240 ECTS and the passed enrolment examination. General information on Master in Occupational Safety Engineering study programme are provided in Tables 2 and 3.

Distribution of ECTS points in master academic studies in occupational safety engineering is provided in Fig. 1. The other study subjects (curriculum) on occupational safety engineering study programme tackle topics such as hazardous materials and hazardous waste, occupational risk assessment, statistical advanced models, occupational medicine, chemical risk assessment of fire and explosion, system regulations and EU practice in occupational health and safety, occupational noise and human vibration in industry, accidental risk management and the environment, product safety and user/consumer protection and sociological and legal aspects of occupational safety. On the other side, none of the current subjects cover the safety at work from life cycle perspective.

According to the previously defined study subject topic, the goal, outcome, content and realisation of new study subject will be defined in results section.

\section{Results}

Based on the previous literature, the new study subject LCA in the field of safety at work has to cover the following topics (Fig. 2):

- LCA according to ISO 14040 and 14044 international standards

- Relationship between WE-LCA and other LCA approaches: the environmental LCA, S-LCA, life cycle costing organisational LCA and sustainability LCA

- S-LCA for workers stakeholder group: goal and scope definition, S-LCI, social life cycle impact assessment methods and interpretation

- Software support for S-LCA: S-LCA software and S-LCI databases

- Evaluation of products life cycle impact on workers through WE-DALY approach 
Table 2 LCA approaches to assess safety at work (continued)

\begin{tabular}{|c|c|c|c|c|}
\hline Approach & $\begin{array}{l}\text { Social life cycle } \\
\text { assessment }\end{array}$ & $\begin{array}{l}\text { Work environment } \\
\text { disability adjusted } \\
\text { life year }\end{array}$ & $\begin{array}{l}\text { Occupational } \\
\text { LCA }\end{array}$ & $\begin{array}{l}\text { Accident } \\
\text { risk-based } \\
\text { life cycle } \\
\text { assessment }\end{array}$ \\
\hline Acronym & S-LCA & WE-DALY & - & ARBLCA \\
\hline Reference & {$[6]$} & {$[3,7]$} & {$[8]$} & [9] \\
\hline $\begin{array}{l}\text { Developing } \\
\text { basis }\end{array}$ & LCA & $\begin{array}{l}\text { LCA and DALY } \\
\text { units }\end{array}$ & LCA and DALY & $\begin{array}{l}\text { LCA and } \\
\text { quantitative } \\
\text { risk } \\
\text { assessment }\end{array}$ \\
\hline Problem-solving & $\begin{array}{l}\text { Evaluation of social } \\
\text { impacts through the } \\
\text { product's life cycle }\end{array}$ & $\begin{array}{l}\text { Waste } \\
\text { management - } \\
\text { landfilling and } \\
\text { incineration }\end{array}$ & $\begin{array}{l}\text { Assessment of } \\
\text { health impacts } \\
\text { from occupational } \\
\text { exposure to } \\
\text { chemicals }\end{array}$ & $\begin{array}{l}\text { Green and } \\
\text { safe fossil } \\
\text { fuel selection }\end{array}$ \\
\hline Geography & Worldwide & $\begin{array}{l}\text { United States of } \\
\text { America }\end{array}$ & North American & $\begin{array}{l}\text { Canada/ } \\
\text { potentially } \\
\text { worldwide } \\
\end{array}$ \\
\hline Characterisation & $\begin{array}{l}\text { Assessment of the } \\
\text { performance of the } \\
\text { sectors and } \\
\text { companies, } \\
\text { respectively, based } \\
\text { on the status of the } \\
\text { indicators taking } \\
\text { the performance of } \\
\text { the sector/company } \\
\text { in relation to the } \\
\text { situation in the } \\
\text { country/region into } \\
\text { account }\end{array}$ & $\begin{array}{l}\text { Characterisation } \\
\text { factors are obtained } \\
\text { from US industry- } \\
\text { level occupational } \\
\text { safety and health } \\
\text { data (work-related } \\
\text { fatal and non-fatal } \\
\text { injuries and } \\
\text { illnesses) and the } \\
\text { physical quantities } \\
\text { of goods produced } \\
\text { by these industries }\end{array}$ & $\begin{array}{l}\text { Based on labour } \\
\text { hours and indoor } \\
\text { intake } \\
\text { concentration }\end{array}$ & IPCC $^{\mathrm{d}}$ \\
\hline $\begin{array}{l}\text { No. of impact } \\
\text { categories/ } \\
\text { indicators }\end{array}$ & $\begin{array}{l}8 \text { - within workers' } \\
\text { stakeholder } \\
\text { category, the } \\
\text { subcategories are } \\
\text { the following: } \\
\text { freedom of } \\
\text { association and } \\
\text { collective } \\
\text { bargaining, child } \\
\text { labour, forced } \\
\text { labour, fair salary, } \\
\text { working time, } \\
\text { discrimination, } \\
\text { health and safety, } \\
\text { social benefits/ } \\
\text { social security }\end{array}$ & $\begin{array}{l}1 \text { - work } \\
\text { environment DALY } \\
\text { (WE-DALY) }\end{array}$ & $\begin{array}{l}1 \text { - occupational } \\
\text { exposure to } \\
\text { chemicals } \\
\text { expressed in } \\
\text { DALY/h }\end{array}$ & $\begin{array}{l}2-\mathrm{GHG}^{\mathrm{e}} \\
\left(\mathrm{CO}_{2}\right) \\
\text { emissions } \\
\text { converted to } \\
\mathrm{CAD}^{\mathrm{f}} \text { by } \\
\text { carbon tax } \\
\text { for LCA, } \\
\text { and } \\
5 \text { risk loss } \\
\text { categories in } \\
\mathrm{CAD}^{\mathrm{f}}\end{array}$ \\
\hline
\end{tabular}


Table 2 (continued)

\begin{tabular}{|c|c|c|c|c|}
\hline Approach & $\begin{array}{l}\text { Social life cycle } \\
\text { assessment }\end{array}$ & $\begin{array}{l}\text { Work environment } \\
\text { disability adjusted } \\
\text { life year }\end{array}$ & $\begin{array}{l}\text { Occupational } \\
\text { LCA }\end{array}$ & $\begin{array}{l}\text { Accident } \\
\text { risk-based } \\
\text { life cycle } \\
\text { assessment }\end{array}$ \\
\hline Normalisation & $\begin{array}{l}\text { Yes - each } \\
\text { subcategory is } \\
\text { assessed twice with } \\
\text { a colour system } \\
\text { ranging from very } \\
\text { good performance } \\
\text { to very poor } \\
\text { performance and } \\
\text { very negative } \\
\text { impacts to positive } \\
\text { impacts }\end{array}$ & No & No & $\begin{array}{l}\text { British } \\
\text { Colombia } \\
\text { province } \\
\text { carbon tax } \\
\left(30 \mathrm{CAD}^{\mathrm{f}}\right. \\
\text { per metric } \\
\text { ton of } \mathrm{CO}_{2} \\
\text { equivalent) }\end{array}$ \\
\hline $\begin{array}{l}\text { Developed and } \\
\text { provided } \mathrm{LCI}^{\mathrm{a}} \\
\text { database }\end{array}$ & $\begin{array}{l}\text { LCI database is not } \\
\text { provided in the } \\
\text { particular study; } \\
\text { however, S-LCA } \\
\text { databases exist }\end{array}$ & $\begin{array}{l}\text { Yes }-127 \text { WE } \\
\text { characterisation } \\
\text { factors linked with } \\
\text { NAICS }^{c} \text { industry } \\
\text { sectors }\end{array}$ & $\begin{array}{l}\text { Yes - for various } \\
\text { NAICS }{ }^{c} \text { industry } \\
\text { sectors, } \\
\text { characterisation } \\
\text { factors have been } \\
\text { developed for } \\
19069 \text { organic } \\
\text { chemical/sector } \\
\text { combinations }\end{array}$ & None \\
\hline
\end{tabular}

${ }^{a} \mathrm{LCI}$, life cycle inventory

${ }^{\mathrm{b}} D A L Y$ disability-adjusted life years

${ }^{\mathrm{D}} N A I C$, North American Industry Classification System

${ }^{\mathrm{d}} I P C C$ Intergovernmental Panel on Climate Change

${ }^{\mathrm{e}} G H G$ greenhouse gases

${ }^{\mathrm{f}} \mathrm{CAD}$ Canadian dollar

Table 3 General information on master in occupational safety engineering study programme [10]

\begin{tabular}{l|l}
\hline Type of studies & Master academic studies \\
\hline Academic degree & $\begin{array}{l}\text { Master in Occupational Safety Engineering (M. } \\
\text { Occ.Saf.Eng.) }\end{array}$ \\
\hline Educational field & Technical-Technological Science \\
\hline Scientific, professional or art field & $\begin{array}{l}\text { Environmental and Occupational Safety } \\
\text { Engineering }\end{array}$ \\
\hline Duration (year/sem) & 1 year/2 semesters \\
\hline $\begin{array}{l}\text { Total European Credit Transfer System } \\
\text { (ECTS) points }\end{array}$ & 60 \\
\hline $\begin{array}{l}\text { Web address containing study programme } \\
\text { information }\end{array}$ & http://www.ftn.uns.ac.rs \\
\hline
\end{tabular}




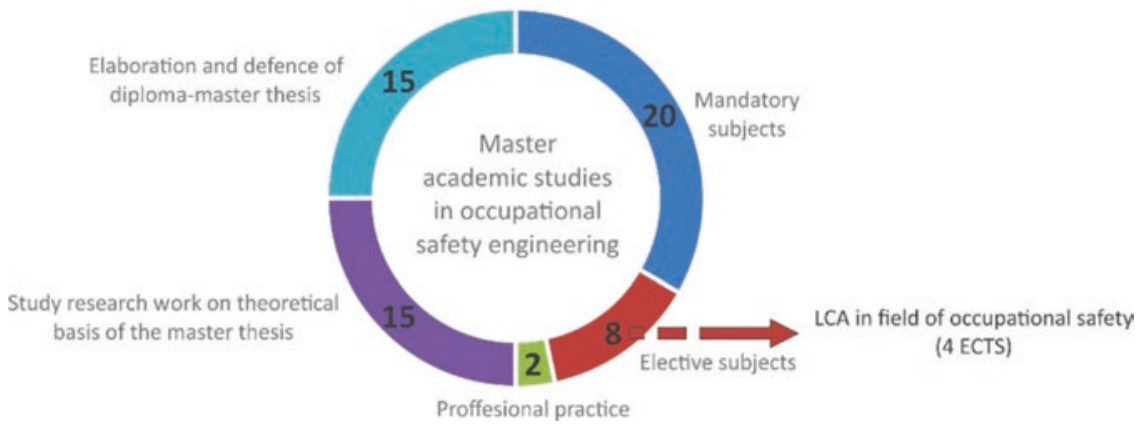

Fig. 1 Distribution of ECTS points in master academic studies in occupational safety engineering

Fig. 2 Topics in study subject LCA in the field of occupational safety

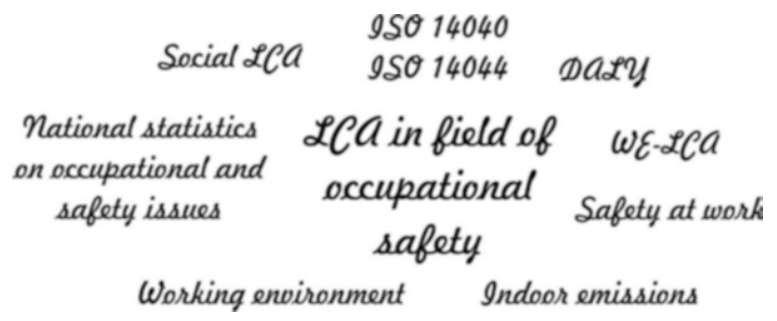

- Evaluation of products life cycle impact on workers through the WE-LCA approach

Fundamentals for teaching will certainly include recommendations for LCA from ISO 14040 and 14044. These standards provide basics for environmental LCA and are nowadays incorporated in other LCA approaches. Historical development, similarities and differences between the various LCA approaches are interesting starting point for better understanding of LCA in the field of safety at work. Within S-LCA, besides other social issues, evaluation of occupational safety is expressed through the workers stakeholder impact category. Software support for S-LCA enables practical calculations of social impacts, supply chain modelling and connection between the industry sectors and countries. Therefore, S-LCA software can be used for performing exercises in computer classrooms with students. WE-DALY and WE-LCA approaches have their LCI database which also can be used for exercises in computer classrooms with students.

The new subject LCA in the field of safety at work on a master study programme of occupational safety engineering at the Faculty of Technical Sciences in Novi Sad has been developed and applied for the accreditation programme for the new 2020/2021 academic year. Goal, outcome, content and realisation of this subject are provided in the following part:

- Goal: Acquisition of knowledge, competences and academic skills in field of safety at work and product's life cycle. Development of creative capabilities, 
academic and practical skills for implementation of life cycle assessment of processes and products from aspect of impact on the worker;

- Outcome: Ability to solve real problems in the field of life cycle assessment of product's impact on worker. Mastering methods and procedures for life cycle assessment of product's impact on worker. Development of skills for life cycle assessment of product's impact on worker with respecting the sustainable development principles. Ability to critically and self-critically think within interpretation of product's and process's life cycle assessment results.

- Content: Product's life cycle. Life cycle assessment in the field of environmental protection and safety at work. Sustainable development, economic, social and environmental dimension within the life cycle assessment. Defining goal and scope of study. Life cycle inventory. Life cycle inventory databases. Life cycle impact assessment on worker. Methods for life cycle impact assessment of products and processes on worker. Interpretation of results.

- Realisation: Lectures are interactive in the form of lectures, auditory, laboratory and computer practice. During the lectures, theoretical part of the course is presented followed by typical examples for better understanding. During the auditory practice, typical problems are solved and the knowledge is deepened. During the computer practice, information communication technologies are applied in order to master the knowledge of the observed field. Besides lectures and practice, consultations are held on a regular basis.

Besides the lectures, this study subject is based on exercises where students can obtain practical knowledge. The exercises have to be based on interactive relationship between the lecturer and students and use of modern educational equipment, computers and the Internet. Mastering methods from this study subject will enable students to perform and develop skills for LCA of product's and process's impact on worker health and safety.

\section{Conclusions}

Although the environmental LCA is well known, the social LCA and LCA in the field of safety at work are starting to gain their momentum in scientific community. The new study subject LCA in the field of safety at work on a master study programme of occupational safety engineering at the Faculty of Technical Sciences in Novi Sad aims to enable students to master these methods and to perform and develop skills for LCA of product's and process's impact on worker health and safety. The objective is to achieve student's scientific competencies and academic skills in the field of LCA and occupational safety. One of the specific objectives is to develop students' awareness of the need for continuous education in the field of occupational safety and the development of a society in general.

The educational framework in this paper is developed for the purposes of occupational safety engineering study programme at the Faculty of Technical Sciences 
in Novi Sad. However, this framework can be applied at other study programmes and universities with certain modifications according to their specific needs. Further development directions will be detected after implementation of LCA in the field of safety at work study subject.

\section{References}

1. UNEP/SETAC, Guidance for Social Life Cycle Assessment of Products. Life-Cycle Initiative, United Nations Environment Programme and Society for Environmental Toxicology and Chemistry, Paris, France, 2009.

2. Schmidt, A., Poulsen, P. B., Andreasen, J., Fløe, T., \& Poulsen, K. E.(2004). LCA and the working environment. Environmental Project No. 907, Danish Environmental Protection Agency.

3. Scanlon, K. A., Lloyd, S. M., Gray, G. M., Francis, R. A., \& LaPuma, P. (2014). An approach to integrating occupational safety and health into life cycle assessment: Development and application of work environment characterization factors. Journal of Industrial Ecology, 19(1).

4. Pettersen, J., \& Hertwich, E. G. (2008). Occupational health impacts: Offshore crane lifts in life cycle assessment. International Journal of Life Cycle Assessment, 13, 440-449.

5. Kim, I., \& Hur, T. (2009). Integration of working environment into life cycle assessment framework. International Journal of Life Cycle Assessment, 14, 290-301.

6. Ciroth, A., \& Franze, J., LCA of an ecolabeled notebook - Consideration of social and environmental impacts along the entire life cycle, Berlin 2011.

7. Scanlon, K. A., Gray, G. M., Francis, R. A., Lloyd, S. M., \& LaPuma, P. (2013). The work environment disability-adjusted life year for use with cycle assessment: A methodological approach. Environmental Health, 12(21).

8. Kijko, G., Margni, M., Parovi-Nia, V., Doudrich, G., \& Jolliet, O. (2015). Impact of occupational exposure to chemicals in life cycle assessment: A Novel characterization model based on measured concentrations and labor hours. Environmental Science \& Technology, 49, $8741-8750$.

9. Khakzad, S., Khan, F., Abbassi, R., \& Khakzad, N. (2017). Accident risk-based life cycle assessment methodology for green and safe fuel selection. Process Safety and Environmental Protection, I09, 268-287.

10. FTS - Master in Occupational Safety Engineering study programme. http://www.ftn.uns.ac.rs/ n1473594640/safety-at-work (Accessed 04.02.2020)

Open Access This chapter is licensed under the terms of the Creative Commons Attribution 4.0 International License (http://creativecommons.org/licenses/by/4.0/), which permits use, sharing, adaptation, distribution and reproduction in any medium or format, as long as you give appropriate credit to the original author(s) and the source, provide a link to the Creative Commons license and indicate if changes were made.

The images or other third party material in this chapter are included in the chapter's Creative Commons license, unless indicated otherwise in a credit line to the material. If material is not included in the chapter's Creative Commons license and your intended use is not permitted by statutory regulation or exceeds the permitted use, you will need to obtain permission directly from the copyright holder.

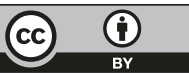

